\section{SM Tropical}

Medicine Journal

\section{Biochemical Changes in the Rumen} Infecting Paramphistome, Gastrothylax crumenifer during Miracidial and Intramolluscan Developmental Stages

\author{
Mohammad Khalid Saifullah ${ }^{1}$, Gul Ahmad ${ }^{2 \star}$, Syed Mohammad Abbas Abidi ${ }^{1}$ and \\ Sabiha Khatoon ${ }^{1}$ \\ ${ }^{1}$ Section of Parasitology, Department of Zoology, Aligarh Muslim University, India \\ ${ }^{2}$ Department of Natural Sciences, Peru State college, USA
}

\begin{abstract}
Article Information
Received date: Dec 15, 2015

Accepted date: Jan 23, 2016

Published date: Jan 27, 2016

*Corresponding author
\end{abstract}

Gul Ahmad, Department of Natural Sciences, Peru State college, USA, Email: gahmad@peru.edu

Distributed under Creative Commons CC-BY 4.0

Keywords Bubalus bubalis; Paramphistome; Gastrothylax crumenifer, Larval Stages; Gyraulus convexiusculus; Biochemical Components

Article DOI 10.36876/smtmj.1002

\section{OPEN ACCESS}

ISSN: 2573-363X

\section{Abstract}

We hypothesize that the level of various biomolecules is variable and remain in a dynamic state during the course of development in Gastrothylax crumenifer. The aim of the present study is to determine whether these molecules are in dynamic state or their levels are constant in all the developmental stages. The present study was designed to investigate level of various macromolecules e.g. protein, glycogen, lipid, lipid fractions and nucleic acids by standard Spectrophotometric methods. All the biomacromolecules are expressed in terms of $\mathrm{mg} / \mathrm{g}$ wet weight. A minimum of three separate replicates were run for each experiment. To investigate similarities/ differences in polypeptides of different developmental stages namely fresh eggs, eggs containing mature miracidia (Em), cercariae, metacercariae, immature and adult stages, SDS-gradient PAGE was performed. In the present study we have investigated biochemical alterations during the larval stages of Gastrothylax crumenifer (a rumen infecting paramphistome) which revealed marked differences during the miracidial development as well as in the intra-molluscan larval stages. We observed that the protein, glycogen and lipid of freshly laid eggs were utilized during the development. Concentration of protein, glycogen and lipid contents significantly elevated in the cercariae as compared to the non-feeding metacercarial stage, indicating an adaptation of the parasite to build up the nutrients for the metacercariae which is a dormant stage. Very little amount of lipid was detected in the fresh eggs (E0) which further decreased in the eggs containing mature miracidia $(E m)$ and then increased sharply in the cercarial and metacercarial stages indicating the substantial buildup of lipid reserves. Nucleic acid contents decreased from E0 to the subsequent developmental stages. Such changes could be of intrinsic significance for the cellular differentiation and organogenesis in larval paramphistomes. Further, we analyzed polypeptide profile of developmental stages which revealed heterogeneous mixture of polypeptides. A total of $27,15,14,15,14$ and 34 polypeptides in E0, Em, cercariae, metacercariae, immature and adult G. crumenifer, respectively were resolved. Eight and nine characteristic polypeptides (17-90 kDa) were observed in E0 and adult stages respectively.

\section{Introduction}

Paramphistomes are commonly occurring digenetic trematodes causing the disease 'parmphistomosis' in ruminants. The disease parmphistomosis causes high morbidity and mortality in tropical and subtropical countries resulting in great economic losses [1]. Gastrothylax crumenifer is an elongated circular paramphistome found in the rumen and reticulum in sheep, cattle and buffalo. The available literature and studies from our laboratory have indicated that $60-80 \%$ of the buffaloes slaughtered have paramphistome infections in various parts of India [2,3]. The problem of paramphistomosis has been comprehensively reviewed by Horak [4] and Dutt [5]. In a survey from our laboratory on the prevalence of paramphistomosis, $71.4 \%$ of buffaloes examined were infected with adults of Paramphistomum epiclitum (51.9\% prevalence), G. crumenifer (32.7\%), Orthocoelium scoliocoelium (16.1\%), Fischoederius elongatus (6\%), Calicophoron papillosum (5\%), C. calicophorum (2\%), Olveria indica (0.34\%) and Gigantocotyle explanatum (19.6\%) [6]. The adult worms inhabiting the rumen have low pathogenicity while the migrating immature stages cause severe pathological disturbances $[4,7,8]$ including hemorrhagic inflammation in the alimentary tract, edema and anemia. The damage caused in ruminants badly influences production, since these parasites cause a lower feed conversion, weight loss, decrease in milk production and responsible for major economic losses [9].

During the completion of life cycle paramphistomes pass through a succession of environments i.e. free living to tissues of intermediate and definitive hosts undergoing multiplication for genome amplification during their life cycle. Inside the definitive host, parasites pass through diversified micro-environments by regulating a sequence of metabolic switches. The regulatory activities and the response of parasites to the environmental changes are discernible at the morphological, reproductive and even at the molecular level for improved survival strategies and to ensure the establishment of their germ line. Thus any change in the organic state of the habitat or its physico- 
Table 1: Shows variation in the level of major biochemical components during the developmental stages of Gastrothylax crumenifer.

\begin{tabular}{|l|c|c|c|c|c|}
\hline Biochemical & $\begin{array}{c}\text { Fresh } \\
\text { eggs } \\
\text { components }\end{array}$ & $\begin{array}{c}\text { Eggs } \\
\text { (0 day } \\
\text { eggs) } \\
\text { containing } \\
\text { mature } \\
\text { miracidia }\end{array}$ & Cercariae & Metaceracriae & Immature \\
\hline Protein & 177.59 & 120.76 & 88.02 & 74.22 & 13.02 \\
& \pm 13.38 & \pm 12.58 & \pm 13.23 & \pm 11.06 & \pm 2.21 \\
\hline Glycogen & 19.28 & 11.577 & 7.03 & 6.012 & 3.908 \\
& \pm 1.89 & \pm 1.14 & \pm 1.55 & \pm 1.96 & \pm 1.13 \\
\hline Lipid & 1.069 & 0.951 & 13.13 & 10.38 & 0.647 \\
\hline Nucleic Acids & \pm 0.96 & \pm 0.11 & \pm 0.78 & \pm 0.85 & \pm 0.09 \\
\hline RNA & 17.30 & 15.12 & 11.81 & 9.760 & 5.691 \\
\hline DNA & \pm 1.13 & \pm 1.61 & \pm 1.19 & \pm 1.42 & \pm 1.01 \\
\hline & 3.931 & 4.590 & 3.031 & 2.150 & 1.371 \\
& \pm 0.815 & \pm 1.01 & \pm 0.929 & \pm 0.139 & \pm 0.214 \\
\hline
\end{tabular}

All the values are mean of three separate replicates, expressed in $\mathrm{mg} / \mathrm{g}$ wet weight.

\pm SEM: indicates standard error of mean.

chemical condition is reciprocated by the parasites through its metabolic features. Most of the morphological, physiological, biochemical and immunological studies are confined to adult parasites only [10-26] while other developmental stages particularly the free living stages and those infecting the intermediate molluscan host, are almost neglected.

In the present communication an attempt has been made to investigate the biochemical alterations during the course of miracidial development and intra-molluscan stages in the gastropod Gyraulus convexiusculus. Comparison of biomolecules and polypeptide profile during the developmental stages will help to understand the dynamics of biochemical turnover and to identify the gene products, which might be associated with the developmental process. The present study may provide an insight to exploit the biochemical peculiarities in the adult as well as larval stages in drug designing to control the menace of paramphistomosis.

\section{Materials and Methods}

\section{Collection of adult and larval stages of Gastrothylax crumenifer}

The adult and immature ( $2 \mathrm{~mm}$ size) Gastrothylax crumenifer parasites were collected from the rumen of Indian water buffaloes (Bubalus bubalis) slaughtered at the local abattoir. The adult worms were incubated for egg shedding in Hanks' medium at $37^{\circ} \mathrm{C}$ for 7 h. Thereafter, the eggs were collected from the incubation flask. A packed volume $(0.02 \mathrm{ml}$ containing approximately 20,000 eggs $)$ of fresh eggs (E0) was weighed before being taken for the extraction and estimation of various biochemical components. The remaining eggs were incubated for miracidial development in tap water at 28 ${ }^{\circ} \mathrm{C}$ under natural light. The developmental changes were checked under microscope and water was changed daily. The incubated eggs containing fully developed miracidia (Em) showing brisk ciliary movements were used on the 8th day post-incubation before the hatching started.

The cercariae were collected from naturally infected gastropod Gyraulus convexiusculus obtained from local ponds during the month of July to September. The cercariae which exhibited brisk movement after emergence from the infected snails were collected and immediately stored at $-20^{\circ} \mathrm{C}$ until use.
To obtain metacercariae, the infected snails were kept in a beaker containing water and grass blades. The emerging cercariae were allowed to encyst on grass blades. Soon after encystation the metacercariae were detached with the help of a small brush by applying gentle pressure and finally collected in an Eppendorf and stored at $-20{ }^{\circ} \mathrm{C}$ until use.

\section{Biochemical estimations}

The alkali soluble glycogen was extracted and estimated by the method of Roe and Dailey [27] using rabbit liver glycogen (Sigma USA) as standard. Protein content was determined following the method of Spector [28]. RNA and DNA were estimated according to the method of Dische [29] and Giles and Myers [30] respectively. Total lipids were extracted by the method of Folch, et al. [31] as modified by Misra [32] and estimated by the method of Zöllner and Krisch [33]. The total lipid fractions such as free fatty acids and cholesterol were estimated by the method of Lowry and Tinsley [34], Sackett [35] respectively. The phospholipids were determined by estimating the phosphorus following the method of Rouser, et al. [36]. The values of biochemical components of each developmental stage were subjected to statistical analysis with respect to each other using t-test and the levels of significance were determined as described in Sokal and Rohlf [37].

\section{Electrophoresis}

SDS-PAGE was performed following the method of Laemmli [38] in a separating $7-15 \%$ gradient slab gel and $4 \%$ stacking gel using a vertical slab gel system. The soluble protein sample containing about $70 \mu \mathrm{g}$ protein was mixed with an equal volume of Laemmli's sample buffer (0.625 M Tris-HCl, pH 6.8) containing 20\% SDS and 5\% (v/v) $\beta$-mercaptoethanol and the sample was boiled for $8 \mathrm{~min}$ at $100{ }^{\circ} \mathrm{C}$. Standard high molecular weight marker proteins ranging from 29 $\mathrm{kDa}$ to $205 \mathrm{kDa}$ were purchased from Pharmacia (LKB, Sweden). Electrophoresis was carried out at $6{ }^{\circ} \mathrm{C}$ by applying a constant current of $30 \mathrm{~mA} / \mathrm{slab}$ gels until the marker tracking dye reached $1 \mathrm{~cm}$ above the gel before the end of the electrophoretic run. The electrophoressed gel was Coomassie stained and analyzed.

\section{Results}

Results obtained during the present study revealed differences in the concentration level of biomolecules in fresh eggs (E0), eggs containing mature miracidia $(\mathrm{Em})$, cercariae, metacercariae and immature stages of G. crumenifer. The values obtained for various biochemical components are summarized in Tables 1 and 2 .

Table 2: Shows variation in the level of major lipid fractions during the developmental stages of Gastrothylax crumenifer.

\begin{tabular}{|l|c|c|c|c|c|}
\hline $\begin{array}{c}\text { LIPID } \\
\text { FRACTIONS }\end{array}$ & $\begin{array}{c}\text { Fresh } \\
\text { eggs } \\
\text { (0 day } \\
\text { eggs) }\end{array}$ & $\begin{array}{c}\text { Eggs } \\
\text { containing } \\
\text { mature } \\
\text { miracidia }\end{array}$ & Cercariae & Metaceracriae & Immature \\
\hline Phospholipid & 0.202 & 0.099 & 0.056 & 0.031 & 0.029 \\
& \pm 0.021 & \pm 0.017 & \pm 0.01 & \pm 0.01 & \pm 0.008 \\
\hline Cholesterol & 0.085 & 0.146 & 0.308 & 0.190 & 0.051 \\
& \pm 0.031 & \pm 0.051 & \pm 0.07 & \pm 0.03 & \pm 0.01 \\
\hline Free fatty & 0.049 & 0.306 & 1.174 & 0.835 & 0.122 \\
acids & \pm 0.018 & \pm 0.025 & \pm 0.12 & \pm 0.023 & \pm 0.017 \\
\hline
\end{tabular}

All the values are mean of three separate replicates, expressed in $\mathrm{mg} / \mathrm{g}$ we weight.

\pm SEM: indicates standard error of mean. 


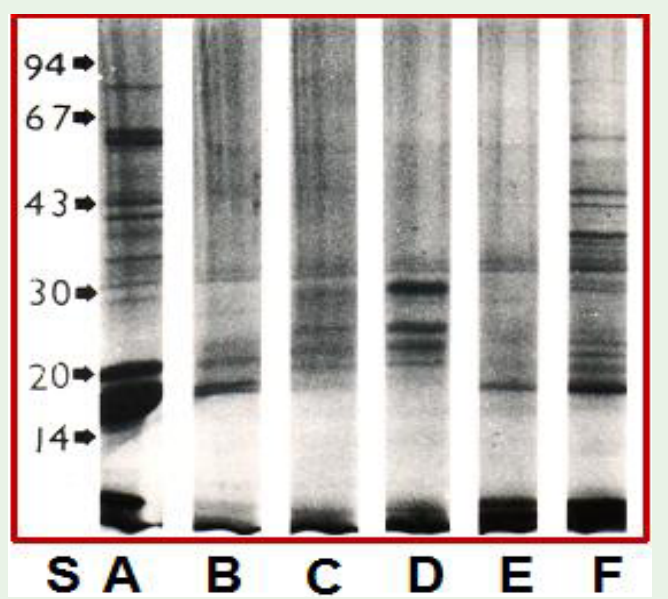

Figure 1: SDS-PAGE Polypepeptide profile of different developmental stages of Gastrothylax crumenifer.

S: Standard molecular weight; A: 0 day eggs; B: Eggs containing mature miracidia; C: Cercariae; D: Metacercariae; E: Immature stage and F: Mature stage.

Higher protein concentration was recorded in the fresh eggs followed by Em, cercariae, metacercariae and immature worms (Table 1). A similar trend was observed for the glycogen in the developmental stages. Differences in the lipid content were also observed in the developmental stages under study. Very little amount of lipid was detected in fresh eggs which further decreased in the eggs containing mature miracidia (Em) but increased sharply in the cercarial and metacercarial stages (Table 2). Comparative analysis of lipid fractions revealed that phospholipid concentration was higher in fresh eggs while cholesterol and free fatty acid fractions were predominant in cercarial stage. The concentration of phospholipids was observed in decreasing order starting from fresh eggs to subsequent developmental stages. However, the level of cholesterol increased up to cercarial stage followed by a decline in the subsequent developmental stages. A similar trend in the free fatty acid level was observed from E0 to immature developmental stages (Table 2). Further, the nucleic acid contents were found to be in decreasing order from E0 onwards to the later developmental stages (Table 2). An overall comparison of RNA and DNA concentration in the developmental stages of G. crumenifer revealed higher concentration of RNA in all the developmental stages.

Analysis of electrophoressed polypeptides revealed that the individual proteins of each developmental stage separated into a heterogeneous mixture of polypeptides of varying molecular weights (Table 3, Figure 1). A total of 27, 15, 14, 15, 14 and 34 distinct protein bands were resolved in fresh eggs (E0), eggs containing mature miracidia $(\mathrm{Em})$, cercariae, metacercariae, immature worm and adult G. crumenifer respectively. Moreover, some stage specific polypeptides were also observed in the developmental stages under study. A total of 8 and 9 specific polypeptides were observed in E0 and adult worm with an apparent molecular weight of 17, 36, $40,45,53,57,70$ and $80 \mathrm{kDa}$ for fresh eggs and 35, 38, 46, 49, 58, $73,85,87$ and $90 \mathrm{kDa}$ for adult fluke. Em, cercariae, metacercariae and immature worms showed only one specific polypeptide with a molecular weight of 18.5, 17.5, 16 and $34 \mathrm{kDa}$ respectively. Further, Em and metacercarial stages did not reveal any specific polypeptide. Besides some fundamental similarities during the development of
Table 3: Shows SDS-PAGE profile of different developmental stage of Gastrothylax crumenifer.

\begin{tabular}{|l|c|c|c|}
\hline $\begin{array}{c}\text { Developmental } \\
\text { stages }\end{array}$ & $\begin{array}{c}\text { Total no. of } \\
\text { polypeptides }\end{array}$ & $\begin{array}{c}\text { Total no. } \\
\text { of specific } \\
\text { polypeptides }\end{array}$ & $\begin{array}{c}\text { Apparent molecular } \\
\text { weight of specific } \\
\text { polypeptides (kDa) }\end{array}$ \\
\hline $\begin{array}{l}\text { Fresh eggs } \\
\text { (0 day eggs) }\end{array}$ & 27 & 8 & $\begin{array}{c}17,36,40,45,53,57,70 \\
\text { and } 80\end{array}$ \\
\hline $\begin{array}{l}\text { Eggs containing } \\
\text { mature miracidia }\end{array}$ & 15 & 1 & 18.5 \\
\hline Cercariae & 14 & 1 & 17.5 \\
\hline Metacercariae & 15 & 1 & 16 \\
\hline Immature & 14 & 1 & 34 \\
\hline Mature & 34 & 9 & $\begin{array}{c}35,38,46,49,58,73,85,87 \\
\text { and } 90\end{array}$ \\
\hline
\end{tabular}

different larval stages under investigation, the protein profile revealed discrete qualitative and quantitative differences. On the basis of present data, the polypeptides can be grouped into three categories, the first category includes 'conserved' polypeptides comprising of those polypeptides which are present throughout the development of parasite, the second category consisted of 'stage specific' polypeptides which are present only in a particular stage of development while the third category includes 'variable' polypeptides which showed inconsistent presence during the course of development. During the present study, polypeptides with apparent molecular weight of 18-20, 25-29, and 55-57 kDa were considered as 'conserved' polypeptides, since these proteins were present in all the stages of G. crumenifer during the course of development. The Em and adult stages did not contain any characteristic polypeptide. The polypeptides with an apparent molecular weight of $30,40,43 \mathrm{kDa}$ were considered as 'variable' polypeptides because of their inconsistent appearance in all the developmental stages.

\section{Discussion}

The life cycle of digenetic trematodes consist of different larval stages, which have strikingly different morphology, live in extremely different environments and express widely different functions. Such diversity can obviously be expected to have a reflection in the biochemical composition of the various forms [39].

The results of present study reveal that levels of major biochemical components like protein, glycogen, total lipid, lipid fractions and nucleic acids are in a dynamic state during the development of larval stages of rumen paramphistome, Gastrothylax crumenifer. The protein, glycogen and lipid contents of G. crumenifer eggs seem to be utilized as a source of nutrient during the course of development. Very little amount of lipids is found in the fresh eggs (E0) and it further decreases in the eggs containing mature miracidia (Em) but increases sharply in the cercarial and metacercarial stages indicating the substantial build up of lipid reserves. Further, the nucleic acid contents were on decrease from eggs to the subsequent developmental stages. The biochemical concentration of protein, glycogen and lipid contents was found to be higher in the free living mature cercaria as compared to the non-feeding dormant metacercarial stage, during the present study. The higher level of these biochemical components in the cercariae of G. crumenifer may be an adaptation because the subsequent metacercarial stage remains in a dormant state until it infects the definitive host. It is well known that the intramolluscan 
larval stages show preference towards the hepatopancreas which is a nutritionally rich organ of the snail and during multiplication process the increased feeding by the larvae may help in food storage for the later developmental stages. Protein synthesis undoubtedly proceeds at a higher rate in the larval parasites because the larvae not only build their own tissues but also those of the individuals of subsequent generation [40]. Studies concerned with the protein synthesis have also been carried out in other developmental stages like rediae, sporocysts or cercariae of a number of trematode species, e.g. Glypthelmins spp., Gorgoderaamplicava and Echinoparyphium sp. [41]. The gradual decline in the protein content of the eggs during the miracidial development in the present study suggests that proteins may be involved in cellular differentiation, organogenesis and other metabolic processes as also reported in a similar study by Wilson [42] who observed a significant decline in the protein and carbohydrate reserves of the eggs during the development of $F$. hepatica miracidia. Marginal decrease in the energy reserves during the later phase of miracidial development of $G$. crumenifer reflects a slow rate of metabolism which may be due to glycogenolysis [43]. Rogers and Petronijevic [44] suggested that the development of an organism is controlled by sets of genes which are activated or suppressed on receiving an appropriate stimulus involving complex interaction between intrinsic and extrinsic factors at a specific stage of the life cycle. Such controlled genes may also be responsible for contributing the differential antigen/protein turnover in parasites. The proteins are of obvious interest because they are the first conceivable product of gene activity involving development of new structures and physiological activities which are linked with these molecules besides immunologically linked activities.

The presence of a large amount of glycogen in the freshly collected eggs of G. crumenifer and a gradual decline in their levels during the later developmental stages clearly indicates that these components are being actively utilized for somatic differentiations of the miracidia and other developmental stages. Horstmann [45] and Wilson [42] have also reported a decline in the glycogen level and oxygen consumption during the miracidial development of $F$. hepatica. The glycogen content of transforming G. crumenifer cercariae into immature stage revealed nearly $45 \%$ decline under present investigation. In earlier studies it has been reported [46] that 50\% decrease in carbohydrate/protein ratio, during the transformation from cercariae to schistosomule. The loss of carbohydrate material was also reflected in the intensity of PAS-stained electrophoretic bands of schistosome larval extracts. Gazzinelli, et al. [47] reported the loss of total carbohydrate and protein from the transforming cercariae. They (loc.cit) determined that two polysaccharide bands obtained from cercarial extracts were much reduced in schistosomule preparations. Studies on the carbohydrate metabolism of the intramolluscan stages have been generally restricted to a few species e.g. Schistosoma spp. [48-50], Cercaria helvetica [51,52], Cercaria linearis and F. hepatica $[53,54]$. Histochemical studies by Cheever and Weller [55] and Cheng and Snyder [56] have revealed that the cercariae and rediae were rich in glycogen. In schistosome cercariae the tail acts a major reserve of nutrients comprising the glycogen and cytochrome oxidase [40] Little is known about the carbohydrate metabolism of metacercariae which is considered to be a dormant stage. Studies on metacercariae are more or less fragmentary and primarily of descriptive nature $[57,58]$. However, a number of aspects on carbohydrate metabolism such as glucose uptake, glucose leakage and the effect of starvation on glycogen content of the non-dormant progenetic metacercariae Clinostomum complanatum have been observed by Siddiqui and Nizami [59]. These authors (loc cit.) reported high levels of glycogen in the C. complanatum metacercariae which may be because this parasite inhabits a semi-anaerobic environment and being a transitional stage in the development, requires more energy for growth and metabolism. Occurrence and utilization of glycogen in Cyclocoelum oculeum [60], Schistosoma mansoni and S. japonicum [61] has also been reported. Variations in the biochemical contents have also been observed during the miracidial development of an amphistome Gigantocotyle explanatum[43].

The level of RNA concentration constitutes a marker for over all metabolic activity [62] in an organism. The elevation of RNA concentration in the larval stages of G. crumenifer during the present study suggests the possibility of activation of development regulatory genes as well as somatic growth and differentiations.

During the present study, changes in lipid level of developing miracidia were significant $(\mathrm{p}<0.05)$. Further, significantly high $(p<0.001)$ level of lipid was recorded in cercariae and metacercariae. It can be suggested that the lipids in developing miracidia are possibly stored for utilization in the subsequent stages of the life cycle [42]. In the present study, increased level of lipids in cercarial stage as compared to the metacercariae indicates rapid synthesis. The possible reason for the higher concentration of lipid could be because the cercariae occupy a nutritionally rich habitat, the hepatopancreas which might be a contributing factor in a nutritionally rich habitat and building the nutritional reserve for the dormant metacercarial stage. Higher lipid content was also reported in the fish infecting C. complanatum metacercariae which could be an adaptation for long survival strategies [59]. This may also be true for the higher concentration of lipid contents in G. crumenifer metacercariae under study, because the stored lipids not only help in the survival of the metacercariae but they are also utilized by the adult worms during the egg production $[57,63,64]$. The difference in lipid and their fractions in the developmental stages under study can be correlated with the metabolic and physiological differences of their microhabitat which are influenced by the effects of various environmental factors. Further, Vykhrestyuk and Yarygina [65] have suggested that the inconsistency in the lipid composition of parasites may depend on factors like parasite species, sex, age and environmental factors like habitat and diet of the host. Among the major lipid fractions in $G$. crumenifer developmental stages the phospholipids concentration was observed higher followed by cholesterol and free fatty acids. The major lipid fractions were triglycerides followed by cholesterol, free fatty acids and phospholipids. Fairbairn [66] and Barrett [67] have reported the utilization of esterified fatty acids and triacyl glycerol for energy release during the embryonation of Ascaris eggs. Higher level of free fatty acids in the eggs containing mature miracidia (Em) stage of G. crumenifer can be suggested as a biochemical adaptation for the subsequent free living developmental phase. This is significant because, fatty acids provide more metabolic water upon oxidation than other metabolic fuels [68]. High concentrations of free fatty acids have also been reported from a number of nematode larvae $[69,70]$. Further, Lee and Song [70] reported an increase in the cholesterol of A. suum during the development of eggs. Decline in the level of phospholipids from fresh eggs to the subsequent developmental stages of $G$. crumenifer, indicates their involvement in molecular reorganization and metabolism. Among various lipid 
fractions of C. complanatum metacercariae, triglycerides account for high percentage while the cholesterol and free fatty acids were observed in approximately similar amounts [59]. A similar trend was reported for adult Dugesia dorotocephala [71], S. mansoni [72] as well as G. crumenifer, Cotylophoron cotylophorum, G. explanatum, F. buski, Isparorchis hypselobagri and Gastrodiscoides hominis [73,74]. Thus it can be suggested that levels of total lipids and their fractions in developmental stages of G. crumenifer during present investigation are controlled by both external and internal environmental conditions which the parasite encounters during thermal and nutritional acclimatization.

Analysis of the protein profile of various developmental stages of G. crumenifer revealed quantitative as well as qualitative variations. Apart from some fundamental similarities, proteins of 'conserved', 'stage specific' and 'variable' nature were also identified. The conserved polypeptides like 18-20,25-29 and 55-75 kDa were present throughout the developmental stages, viz. fresh eggs (E0), eggs containing mature miracidia (Em), cercariae, metacercariae, immature (size, $2 \mathrm{~mm}$ ) and adult worms under study while the stage specific polypeptides were characteristic of a particular stage only. Similarly, Anderson [75] observed a total of 20 conserved polypeptides (MW 23-220kDa) in the soluble proteins of 4.5, 8, 11 and 18 week old F. hepatica. The surface protein of schistosomula and adult stages also revealed a number of conserved polypeptides in the molecular weight range of $16-150 \mathrm{kDa}$ [76]. In the cestode parasite Echinococcus granulosus, the conserved group of polypeptides included a wide range of varying molecular weight $(<29$ to $153 \mathrm{kDa})$ polypeptides [77]. On the other hand some variable polypeptides were also observed during the present study. Unfortunately, no previous report on the protein turn over during the course of development is available from any other amphistomes; therefore the present work is just a beginning to open further avenues for research in this direction. The SDS-PAGE results resolved a minimum of 14 and a maximum of 34 protein bands in the protein sample of developmental stages under study and it was observed that three polypeptides of 24, 28 and $43 \mathrm{kDa}$ in E0 and Em stages, six polypeptides of $16,20,21.5,23,25$ and $28 \mathrm{kDa}$ in cercariae and metacercariae while eight polypeptides of 18, 19, 20, 25, 28, 30,40 and $50 \mathrm{kDa}$ in immature and mature worms were of similar intensity. A similar pattern was recorded by Ruppel and Cioli [78] who observed some dissimilarity in the protein profiles of mature and immature schistosomes as well as male and female worms. During the present study, polypeptides of 58 and $23 \mathrm{kDa}$ molecular weight were observed specific to the adult $G$. crumenifer, which was conspicuously absent in all the other developmental stages. The stage specific protein with a molecular weight of 58 and $23 \mathrm{kDa}$ might be associated with appearance of some important adult structure like the intestine and its contents as has also been suggested by Ruppel and Cioli [78] for schistosomes. It seems that in spite of great morphological differences during the development, specialized structures characteristic of each stage emerge as differences in protein composition, if they represent a sizable portion of the total parasite tissues. In addition to this, we reported earlier some conserved and species specific polypeptides in the fresh eggs of five amphistomes species [79]. Moreover, variations in the soluble egg polypeptide profile of three isolates of S. mansoni of different geographical regions are on record [80-83]. Occurrence of 'conserved', 'stage specific' and 'variable' polypeptides in the developmental stages of G. crumenifer during the present study requires further studies to ascertain their functional role as well as biochemical nature so that the polypeptides of interest may be used in chemotherapeutic modulation to block reproduction and development of the parasite.

Taken together, it can be said that the fluctuations in the biochemical components like protein, glycogen, lipid, lipid fractions, RNA and DNA of developmental stages of the rumen amphistome G. crumenifer, may either be a characteristic of a particular developmental stage under study or else may be due to the influence of various physico-chemical factors of different micro-habitats. It could also be a biochemical adaptation to meet the metabolic requirements. Thus, it can be concluded that the variation in the metabolic turnover accompanying the transition from one larval stage to the next involves quantitative as well as qualitative changes in components which may be greatly influenced by various physico-chemical factors of different micro-habitats.

\section{Acknowledgement}

The authors are grateful to the Chairman, Department of Zoology for providing laboratory facilities. MKS is thankful to UGC, Govt. of India for providing financial support (Grant no. F.No. 37612/2009(SR)).

\section{References}

1. Mukherjee RP, Chauhan BS. Studies on the trematodes fauna of India, Part V. Subclass Digenea: Paramphistomidea, Fischoeder (1901). J Zool Soc Ind. 1965; 17: 150-225.

2. Dunn TS. Epidemiological, histological and histochemical studies on amphistomes parasites (Trematoda:Digenea) of the Indian water buffalo, Bubalus bubalis. Ph.D. Thesis. The Queen's University of Belfast, Northern Ireland. 1984.

3. Gupta RP, Chaudhari SS, Ruprah NS, Yadav CL. Epizootiology of paramphistomiasis in Haryana State. Indian J Anim Sci. 1985; 55:14-19.

4. Horak IG. Paramphistomosis of domestic ruminants. Adv Parasitol. 1971; 9: 33-72.

5. Dutt SC. Paramphistomes and paramphistomosis of domestic ruminants in India. Ludhiana, India, Punjab Agricultural University Press. 1980.

6. Mattison RG, Abidi SMA, Nizami WA, Hanna REB. Preliminary studies in the numerical systematics of the Paramphistomoidea (Digenea) from domestic Artiodactyla of Northern India. Syst Parasitol. 1994; 27: 81-103.

7. Noble ER, Noble GA. The Biology of Animal Parasites. Lea \& Febiger, Philadelphia. 1982: 174-175.

8. Hanna REB, Willamson DS, Mattison RG, Nizami WA. Seasonal reproduction in Paramphistomum epiclitum and Gastrothylax crumenifer rumen amphistomes of the Indian water buffalo and comparison with the biliary amphistome Gigantocotyle explanatum. Int J Parasitol. 1988; 18: 513521.

9. Spence SA, Fraser GC, Chang S. "Response in milk production to the control of gastrointestinal nematode and paramphistomes parasites in dairy cattle". Aust Vet J. 1996; 74: 456-459

10. Khan P, Nizami WA, Ahmad M, Abidi SMA. Biochemical Variations in Gigantocotyle explanatum and Gastrothylax crumenifer with respect to their seasonal reproduction. Int J Parasitol. 1990; 20: 109-117.

11. Saifullah MK, Nizami, WA. Egg protein profile of some digenetic trematodes (Abstract)Eleventh national Congress of Parasitology, Udaipur, India. 1994; 172-173.

12. Abidi SMA, Nizami WA. Monoamine oxidase in amphistomes and its role in worm motility. J Helminthol. 2000; 74: 283-288. 
13. Saifullah MK, Ahmad G, Nizami WA. Analysis of excretory/secretory and somatic antigens of Gastrothylax crumenifer (Trematoda:Digenea). J Helminthol. 2000; 74: 271-276.

14. Saifullah MK, Ahmad G, Nizami WA, Abidi SMA. Partial purification and characterization of Gastrothylax crumenifer somatic antigens. Vet Parasitol. 2000; 89: 23-29.

15. Saifullah MK, Ahmad G, Nizami WA. Effect of parasitism on the biomolecules of Gyraulus convexiusculus hepatopancreas. J Vet Parasitol. 2000; 14: 21 26.

16. Saifullah MK, Abidi SMA, Nizami WA. Tegumental uptake of $14 \mathrm{C}$-glycine by Gastrothylax crumenifer and Gigantocotyle explanatum (Digenea: Paramphistomidae). J Parasit Dis. 2000; 24: 31-38.

17. Saifullah MK, Abidi SMA, Nizami WA. Polypeptide profile of the in vitro released eggs of some digenetic trematodes. J Vet Parasitol. 2001; 15: 2528.

18. Ahmad G, Saifullah MK, Nizami WA. Partial purification and characterization of Gigantocotyle explanatum somatic antigens. J Helminthol. 2004; 76: 95 99.

19. Anuracpreeda P, Wanichanon C, Sobhon P. Paramphistomum cervi: Antigenic profile of adults as recognized by infected cattle sera. Exp Parasitol. 2008; 118: 203-207.

20. Abidi SMA, Khan P, Saifullah MK. Characterization of the glutamate dehydrogenase activity of Gigantocotyle explanatum and Gastrothylax crumenifer (Trematoda: Digenea). J Parasit Dis. 2009; 33: 57-64.

21. Saifullah MK, Ahmad G, Abidi SMA. Isolation and partial characterization of excretory/secretory antigens of Gastrothylax crumenifer. Vet Parasitol. 2011 180: 232-236.

22. Saifullah MK, Ahmad G, Abidi SMA. Immunodetection of coproantigens fo the diagnosis of amphistomosis in naturally infected Indian water buffalo, Bubalus bubalis. Vet Parasitol. 2013; 191: 66-72.

23. Arunkumar S, Krupakaran R, Balamurugan TC, Pandiyan GDV Electrophoretic analysis of excretory/secretor antigens of Gastrothylax crumenifer from buffalo. Cibtech Journal of Bio-Protocols. 2014; 3: 24-26.

24. Jyoti, Prasad A, Singh NK. Evaluation of antibody response to various developmental stage specific somatic antigens of Paramphistomum epiclitum in goats. BioMed Research International. 2014; 2014: 1-6.

25. Tehrani A, Javanbakht J, Khani F, Hassan MA, Khadivar F, Dadashi F, et al Prevalence and pathological study of Paramphistomum infection in the smal intestine of slaughtered ovine. J Parasit Dis. 2015; 39: 100-106.

26. Sujith S, Deepa CK, Priya MN, Darsana U, Sreedevi R, Lucy KM. In vitro Efficacy of Various Extracts of Murraya koenigii Leaf against Gastrothylax crumenifer. Int J Pharmac Phytochem Res. 2015; 7: 604-607.

27. Roe JH, Dailey RE. Determination of glycogen with the anthrone reagent Anal Biochem. 1966; 15: 245-250.

28. Spector T. Refinement of the coomassie blue method of protein quantitation A simple and linear spectrophotometric assay for less than or equal to 0.5 to 50 microgram of protein. Anal Biochem. 1978; 86:142-146.

29. Dische Z. Color reactions. In: The nucleic acids, Vol.I (Charagaff, E. and Davidson, J.N.eds.): Academic Press, New York. 1935; 285-305.

30. Giles K, Myers A. An imported diphenylamine method for the estimation of deoxyribonucleic acid. Nature. 1965; 206: 93.

31. Folch J, Lees M, Sloane Stanley GH. A simple method for the isolation and purification of total lipids from animal tissues. J Biol Chem. 1957; 226: 497 509.

32. Misra UK. Liver lipids of rats administered excessive amounts of retinol. Canad J Biochem. 1968; 46: 697-701.

33. Zöllner N, Krisch K. Uber die quantitative Bestimmung von Lipoiden (Mikromethode) mittles der vielennaturlichemLipoiden (Allen bekannten
Plasmalipoiden) gemeinsamensulphophospho vanillin-Reaktion. Z. gesamteexpe. Med. 1962; 135: 545-561

34. Lowry RR, Tinsley IJ. Rapid colorimetric determination of free fatty acids. J Am Oil Chem Soc. 1976; 53: 470-472.

35. Sackett GE. Modification of Bloor's method for the determination of cholesterol in whole blood or blood serum. J Biol Chem. 1925; 64: 203-205

36. Rouser G, Fkeischer S, Yamamoto A. Two dimensional then layer chromatographic separation of polar lipids and determination of phospholipids by phosphorus analysis of spots. Lipids. 1970; 5: 494-496.

37. Sokal RR, Rohlf FJ. Biometry: The principles and practice of statistics in biological research, $2^{\text {nd }}$ edition. W.H. Freeman, San Francisco. 1981

38. Laemmli UK. Cleavage of structural proteins during the assembly of the head of bacteriophage T4. Nature (London). 1970; 227: 680-685.

39. Barrett J. Biochemistry of Parasitic Helminths. MacMillan, London. 1981.

40. Smyth JD, Halton DW. The physiology of trematodes. Cambridge University press. London. 1983.

41. Cheng TC. Biochemical requirements of larval trematodes. Ann NY Acad Sci. 1963; 113: 289-320.

42. Wilson RA. A physiological study of the development of the egg of Fasciola hepatica L., the common liver fluke. Comp Biochem Physiol. 1967; 21: $307-$ 320.

43. Khan P, Nizami WA, Irshadullah M, Ahmad M. Biochemical changes during the development of the miracidium of Gigantocotyle explanatum. Int J Parasitol. 1991; 21: 731-734.

44. Rogers WP, Petronijevic T. The infective stage and the development of nematodes. Symonds LEA, Donald AD and Dineen JK, editors. In: Biology and control of endoparasites. Academic press, Australia. 1982: 3-28.

45. Horstmann HJ. Sauerstoffverbrauch und Glycogengehalt der Eir von Fasciola hepatica wahrend der Entwicklung der Miracidien. [Oxygen consumption and glycogen content of the ova of Fasciola hepatica during the development of the miracidia]. Z Parasitenkd. 1962; 21:437-445.

46. Oliveira CC, FigueiredoEA, Gazzinelli G, Howells RE. Biochemical changes in the transformation of Schistosoma mansonicercariae to schistosomules. Comp Biochem Physiol. 1975; 51B: 417-420

47. Gazzinelli G, De Oliveria CC, Fiegueiredo EA, Perira LH, Coelho PMZ, Pellergrino J. Schistosoma mansoni: Biochemical evidence for morphogenetic change from cercaria to schistosomule. Exp Parasitol. 1973; 34: 181-188.

48. Coles GC. Carbohydrate metabolism of larval Schistosomamansoni: International J Parasitol. 1972; 2: 341-352.

49. Christie JD. Changes in levels of carbohydrate reserves of Biomphalaria glabrata (Say, 1818) infected with Schistosoma mansoni (Sambon, 1907). Dissertation Abstracts International. 1973; 34B: 464-465.

50. Diconza JJ, Basch PF. Incorporation of 3H-thymidine and $14 \mathrm{C}$-glucose by Schistosoma mansoni daughter sporocysts in vitro. J Parasitol. 1974; 60: 1045-1046.

51. Reader TAJ. Histochemical observation on carbohydrates, lipids and enzymes in digenean parasites and host tissues of Bithynia tentculata. Parasitol. 1971; 63: 125-136.

52. Reader TAJ. Autoradiographic studies on the uptake of $14 \mathrm{C}$-glucose by Bithynia tentculata (Mollusca:Gastropoda) and its larval digeneans. J Helminthol. 1974; 48: 235-240.

53. Humiczewska M. Oxidative enzymes in the development of Fasciola hepatica L.II.Dehydrogenase activity of miracidium. Folia Histo chem Cyto chem. 1975; 13: 37-50.

54. Humiczewska M. Oxidative enzymes in the development of Fasciola hepatica L.III. The activity of oxidases and dehydrogenases in the sporocyst. Folia Histochem Cyto chem. 1975; 13: 51-60. 
55. Cheever AW, Weller TH Observations on the growth and nutritiona requirements of Schistosoma mansoni in vitro. Am J Hyg. 1958; 68: 322-339.

56. Cheng TC, Snyder RW. Studies on host-parasite relationships between larval trematodes and their hosts. I. A review. II. The utilization of the host's glycogen by the intramolluscan larvae of Glypthelmins pennsylvaniens Cheng, and associated phenomena. Trans Am MicroscSoc. 1962; 81: 209228.

57. von Brand T. Biochemistry of parasites. New York and London: Academic Press. 1973

58. Smyth JD. Introduction to animal Parasitology. $2^{\text {nd }}$ edn. London: Hodder and Stoughton. 1976

59. Siddiqui J, NizamiWA. Studies on the lipid metabolism of the metacercariae of Clinostomum complanatum (Trematoda:Digenea). Int J Parasitol. 1981; 11: $115-119$

60. Taft SJ. Histochemistry of the miracidial and early redial stage of Cyclocoelum oculeum (Trematoda: Cyclocoelidae). Proc Helminthol Soc Washington. 1979; 46: 64-69.

61. Axmann MC. Morphological studies on glycogen deposition in Schistosomes and other flukes. J Morphol. 1947; 80: 321-343.

62. Smith FF and Walker CW. Biochemical changes in the composition of the testes during spermatogenesis in the sea star Asterias vulgaris. J Exp Zool. 1986; 237: 351-364.

63. Goil MM. Fat metabolism in trematode parasites. Zeitschri ftfür Parasitenkd. 1958; 18: 320-323.

64. Goil MM. Protein metabolism in trematodes parasites. J Helminthol. 1958; 32: 119-124.

65. Vykhrestyuk NP, Yarygina GV. Preliminary studies of lipids of the trematodes Eurytrema pancreaticum, Calicophoronerschowi and the turbellarian Penecurva sibirica. Mol Biochem Parasitol. 1982; 5: 221-229.

66. Fairbairn D. Embryonic and post embryonic changes in the lipid of Ascaris lumbricoides eggs. Canad J Biol Chem. 1955; 33: 122-129.

67. Barrett J. The effect of ageing on the metabolism of the infective larvae of Strongyloides ratti Sandground, 1925. Parasitol. 1969; 59: 3-17.

68. Murray RK, Granner DK, Maues PA, Rodwell VW. Harper's Biochemistry. 21 edition. Appletom \& Lange, Norwalk, Connecticut/San Mateo. 1988.

69. Barrett J. Lipids of the infective and parasitic stages of some nematodes. Nature (London). 1968; 218: 1267-1268.
70. Lee SH, Song CY, Lee KB and Lee HS. A study on the lipids of Ascarissuum ova. Korean J Parasitol. 1977; 15: 43-50.

71. Meyer F, Meyer H, Bueding E. Lipid metabolism in the parasite and free living flatworms, Schistosoma mansoni and Dugesia dorotocephala. Biochimica et Biophysica Acta. 1970; 210: 257-266.

72. Cicchini T, Belli M, Messesi E, Passi S. Determination of the cercarial lipids and relations with superficial human cutaneous lipids. AnnaliSclavo. 1976; 18: $720-726$.

73. Yusufi ANK, Siddiqi AH. Comparative studies on the lipid composition of some digenetic trematodes. Int J Parasitol. 1976; 6: 5-8.

74. Yusufi ANK, Siddiqi AH. Lipid composition of Gastrodiscoides hominis from pig. Indian J Parasitol 1977; 1: 59-61.

75. Anderson SML. Biochemical and immunological studies of surface components of Fasciola hepatica throughout development. Ph.D. Thesis. The Queen's University of Belfast, U.K. 1989.

76. Philipp M, Rumjaneck FD. Antigenic and dynamic properties of helminth surface structures. Mol Biochem Parasitol. 1984; 10: 245-268.

77. Ali A. Analysis of stage specific gene products and their antigenic nature of Echinococcus granulosus. Ph.D. Thesis. AMU. Aligarh, India. 1996.

78. Ruppel A, Cioli D. A comparative analysis of various developmental stages of Schistosoma mansoni with respect to their protein compositions. Parasitol. 1977; 75: 339-343

79. Saifullah MK, Nizami WA Cytosolic and mitochondrial transaminases of three species of buffalo amphistomes (Trematoda:Digenea). Ind Vet Med J. 1999; 23: 19-26.

80. Carter CE and Colley DG. An electrophoretic analysis of Schistosoma mansoni soluble egg antigen preparation. J Parasitol. 1978; 64: 285-290.

81. Pillay D, Pillay. Random amplified polymorphic DNA analysis shows intraspecies variation among Schistosoma mansoni isolates. Medi Sci Res. 1994: 22 : 369-371.

82. Pillay D. Electrophoretic differentiation of Schistosoma mansonisoluble egg antigens. Proceedings of the Year of Louis Pasteur International Symposium Etiology and Pathogensis of Infectious diseases, Dekar, Senegal. 1995; 1 : 158

83. Pillay D. Electrophoretic differentiation of soluble egg antigens from Schistosoma mansoni isolates using SDS-PAGE. J Helminthol. 1996; 70: 91-93. 